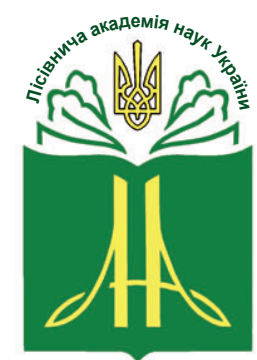

Forestry Academy of Sciences of Ukraine

Наукові праці Лісівничої академії наук України Proceedings of the Forestry Academy of Sciences of Ukraine

http://fasu.nltu.edu.ua

https://doi.org/10.15421/412008

Article received 2020.01.12

Article accepted 2020.06.04
ISSN 1991-606X print

ISSN 2616-5015 online

@ $\square$ Correspondence author

Yuriy Shparyk

yurii.shparyk@pnu.edu.ua

Halytska str., 201, Ivano-Frankivsk, 76008, Ukraine

\title{
Тенденції динаміки типів лісорослинних умов і породного складу деревостанів Українських Карпат у зв'язку зі змінами клімату
}

\author{
Ю.С. Шпарик ${ }^{1}$, Г.Т. Криницькийㄹ, Ю.М. Дебринюк ${ }^{3}$
}

Глобальні зміни клімату вже зараз суттєво змінили умови ведення лісового господарства в Українських Карпатах. Зокрема внаслідок масового всихання ялини багато підприємств змушені переорієнтовувати свої лісівничі заходи на вирощування товарної деревини інших порід. Виявлено два основних напрями кліматогенних змін у лісах регіону: зміна едафотопів лісових ділянок у напрямі покрашення їхньої родючості з одночасним зменшенням вологості, зміна конкурентоздатності різних деревних видів, зміна породного складу лісів. Найбільші зміни відбуваються в ялинових лісах, де місце ялини, щуо всихає, природним шляхом займають ялиия $і$ бук, однак під час створення лісових культур вибір головної породи може бути й іншим. Тому актуальним є виявлення закономірностей изих змін для правильного вибору головних порід за типами лісу $і$ висотними рослинними смугами. Тенденції динаміки лісорослинних умов і породного складу лісів регіону були ідентифіковані за відомчими даними метеостанцій та лісовпорядкування.

Встановлено, щзо кліматогенні зміни лісів Українських Карпат відбуваються у таких напрямах: а) дубовобукові ліси трансформуються в буково-дубові зі зміною гігротопу зі «свіжого» на «сухий»; б) буково-ялицеві ліси - в ялицево-букові зі зміною гігротопу з «вологого» на «свіжий»; в) грабово-букові ліси - в грабово-дубовобукові зі зміною гігротопу з «вологого» на «свіжий»; г) смереково-буково-ялицеві ліси - в смереково-ялицевобукові або ялицево-букові зі зміною гігротопу з «вологого» на «свіжий»; д) буково-ялицево-смерекові ліси - в смереково-ялицево-букові або ялицево-букові зі зміною гігротопу з «сирого» $i$ «вологого» на «свіжий»; е) шільнодернинні луки та полонини інтенсивно заростають смерековими, ялівцевими та душекієвими угрупованнями.

Констатується нагальна потреба в лісотипологічному картуванні лісогосподарських підприємств Карпатського регіону під час проведення їх повторного лісовпорядкування.

Ключові слова: кліматогенні зміни лісів; сума активних температур; кількість опадів; лісовпорядкування; висотні пояси рослинності; тип лісу; тип деревостану.

\footnotetext{
Шпарик Юрій Степанович - член-кореспондент Лісівничої академії наук України, доктор сільськогосподарських наук, професор кафедри лісознавства. Прикарпатський національний університет імені Василя Стефаника, вул. Галицька, 201, м. Івано-Франківськ, 76008, Україна. Тел.: +38-0342-596163,+38-050-188-02-61. E-mail: yurii.shparyk@pnu.edu.ua ORCID: https://orcid.org/0000-0001-80476356

2 Криницький Григорій Томкович - академік Лісівничої академії наук України, Президент ЛАН України, доктор біологічних наук, професор, завідувач кафедри лісівництва. Національний лісотехнічний університет України, вул. генерала Чупринки, 103, м. Львів, 79057, Україна. Тел.: 032-237-89-05,+38-067-784-11-60. E-mail: krynytsk@ukr.net

3 Дебринюк Юрій Михайлович-академік Лісівничої академіїнаук України, академік-секретар ЛАН України, доктор сільськогосподарських наук, професор кафедри лісових культур і лісової селекції. Національний лісотехнічний університет України, вул. генерала Чупринки, 103, м. Львів, 79057, Україна. Тел.: 032-235-30-12, +38-067-195-78-36. E-mail: debrynuk ju@ukr.net ORCID: http://orcid.org/0000-00020994-349X
} 
Вступ. Суттеві кліматичні зміни останніх десятиріч відзначаються вченими різних наукових напрямів і в їхніх висновках переважно йдеться про потепління та зменшення кількості опадів (Jump, Hunt, \& Peñuelas, 2006; Cannone, 2007; Kobiv, 2009; Didukh, Chorney, \& Budzhak, 2016; Shukla et al., 2019). Заклопотаність світової громадськості проблемою зміни клімату відобразилася в ухваленій у 1992 р. рамковій Конвенції ООН про зміну клімату, а в 1997 p. - у Кіотському протоколі. У 1988 р. засновано Міжурядову групу експертів зі зміни клімату (IPCC), яка наразі $€$ найавторитетнішою організацією щодо вивчення змін клімату в регіональному і глобальному масштабах, оцінювання наслідків цих змін та перспектив адаптації до них. У звіті IPCC за 2019 р. відзначено два періоди росту середньорічних значень температури повітря: $з 1920$ до 1940 р. - на $0,5^{\circ} \mathrm{C}$ та 31980 до 2018 р. - більш ніж на $1,5^{\circ} \mathrm{C}$ із збереженням тенденції до збільшення (рис. 1). У цьому контексті важливим для ведення лісового господарства $\epsilon$ висновок, що разом із температурою повітря збільшується і температура поверхні грунту (в період 1980-2018 pр. - також на $\left.1,0^{\circ} \mathrm{C}\right)$. За експертними прогнозами глобальне потепління триватиме навіть у разі зменшення викидів парникових газів в атмосферу (у звіті ілюстровано, що ці викиди зростають) за рахунок інерції кліматичної системи (Shukla et al., 2019).

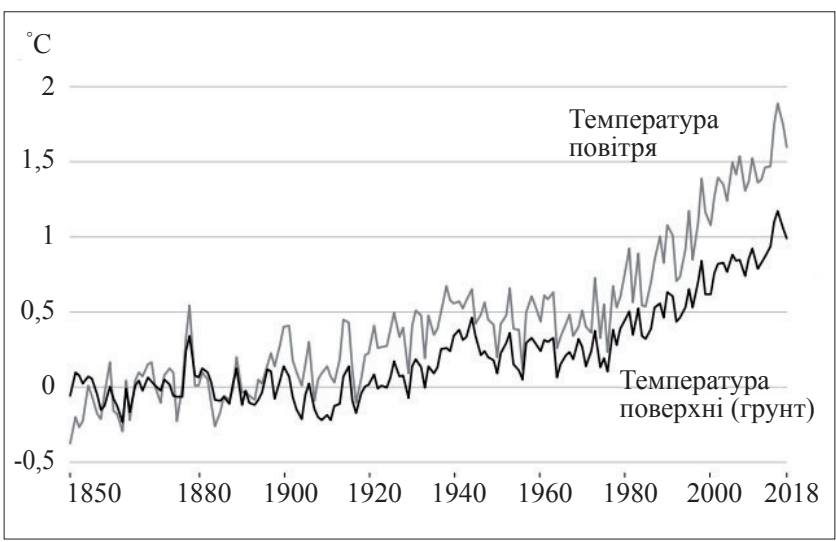

Рис. 1. Динаміка перевищення середньої багаторічної температури Землі (Shukla et al., 2019)

Зміни температури повітря і грунту впливають i на ведення лісового господарства, оскільки саме температурний режим і наявність доступної вологи зумовлюють не лише інтенсивність росту дерев, але й можуть стати причиною зникнення окремих деревних видів і появи більш життєздатних у змінених лісорослинних умовах. Масове всихання ялинників Карпат і $є$ класичним наслідком цих кліматичних змін. Дослідники пояснюють цю регіональну природну катастрофу кліматичною зміною типів лісорослинних умов, насамперед - умов зволоження, які знизили життєздатність Picea abies [L.] Karst. порівняно з іншими деревними видами (Debryniuk, 2011; Shparyk, 2013; Kramarets, 2018). В цьому випадку вже йдеться про зміну меж лісо- рослинних районів, i, відповідно, про зміни у складі рослинних субформацій і формацій.

Вплив кліматичних змін на зміну лісорослинних умов має два основних аспекти: а) глобальне потепління змінює едатопи лісових ділянок у напрямі покращення їхньої родючості (за рахунок інтенсифікації кругообігу речовин за підвищеного температурного режиму) з одночасним зменшенням вологості (за рахунок зменшення кількості опадів i підвищення температури повітря); б) зміна клімату впливає на конкурентоздатність різних деревних видів неоднаково, що може призвести до зміни видового складу корінного деревостану, а також і до зміни типу лісу. Отже, впродовж двох останніх десятиріч у Карпатах спостережено зміну типів лісорослинних умов, яка впливає на видовий склад лісів, їхню продуктивність і біотичну стійкість. У зв'язку з цим, виникає потреба у з'ясуванні меж діючого лісорослинного районування Українських Карпат, в уточненні складу рослинних формацій, що особливо актуально в контексті майбутнього повторного лісовпорядкування лісового фонду лісогосподарських підприємств регіону (Golubets, 2003; Jump et al., 2006; Kobiv, 2009; Didukh et al., 2016; Shparyk \& Viter, 2016).

Об'скти та методика досліджень. Уточнення меж лісорослинних районів у Карпатському регіоні у зв'язку 3 кліматичними змінами передбачає аналіз і синтез значної кількості інформації щодо поширення лісової рослинності, іiї видового складу, стійкості у змінених кліматичних умовах, тобто прийняття до уваги всієї сукупності компонентів природних екосистем, тісно взаємопов'язаних між собою (Vorob'ev, 1967; Ivanenko, 1977; Golubets, 1978, 2003; Gerushyns'kyj, 1996; Stoyko, 2003; Debryniuk, 2003; Shparyk \& Viter, 2012). Зрозуміло, що у форматі статті викласти такий значний обсяг інформації неможливо, тому ми обмежились акцентуванням уваги на впливі кліматичних змін на лісорослинні райони, в межах яких формуються ті чи інші субформації деревної рослинності, а також основні (базові) типи лісу. Зокрема, звернута увага на такі напрями змін: зміну кліматопів, які спричинюють зміну едафотопів; зміну породного складу і структури лісостанів.

Об'єкт досліджень - кліматопи і напрями зміни лісорослинних умов Українських Карпат в контексті кліматичних змін. Предмет дослідження - зміни породного складу і структури лісів. Мета досліджень полягає у встановленні напрямів зміни лісорослинних умов та в уточненні складу деревостанів Українських Карпат за висотними рослинними смугами (вегетаційними ступенями).

Кліматопи визначали за методикою Vorob'ev (1967), а інтенсивність їх зміни та суму активних температур за останнє десятиріччя - за даними погодного сайту rp5.ua. Для цього порівнювали кліматичні показники за весь доступний період спостережень і за останні десять років. Зміни у породному складі і структурі лісів вивчали за даними лісовпорядкування (з реляційної бази даних), а та- 
кож за результатами наукових досліджень (Kobiv, 2009; Shparyk, Viter, 2016; Shparyk, Berkela, Viter, \& Losiuk, 2018; Kramarets, Matsyak, 2018).

Результати та обговорення. Лісові фітоценози у своєму розвитку перебувають у тісній залежності від стану кліматопу. В класичному розумінні кліматоп - це кліматичні межі, в яких формуються певні лісорослинні умови. Вони визначаються наступними річними показниками клімату: сумою середньомісячних температур вищими $0^{\circ} \mathrm{C}(\mathrm{T})$, кількістю опадів за місяці з середньомісячною температурою вищою $0^{\circ} \mathrm{C}(\mathrm{W})$, континентальністю клімату $(\mathrm{A})$ як різницею найбільшої і найменшої середньомісячних температур (Vorob'ev, 1967). Ці показники i відповідні їхні величини були опрацьовані для типів лісу рівнинної частини України, однак для ідентифікації кліматопів у гірських умовах вони не підходять (Shparyk \& Viter, 2016).

Порівняння кліматопів за середніми багаторічними даними та за останні (2010-2019) роки здійснено на основі багаторічних кліматичних даних метеостанцій регіону Українських Карпат (табл. 1). Отримані результати свідчать, що різноманітність кліматопів в гірських лісах дуже значна - від $2 \mathrm{f}$
(Чернівці - за останні 10 років) до 13b (Пожижевська - багаторічні дані). При цьому, клімати гігротопів змінюються від 2 (свіжі) до 13 (немає відповідної назви в класифікації рівнинних типів лісу), а клімати трофотопів - від b (помірно холодні, субори) до g (немає відповідної назви в класифікації рівнинних типів лісу). Найбільш поширеним регіональним багаторічним кліматопом є 5d (мокрі теплі типи лісу), а за останні 10 років - 4е (сирі дуже теплі типи лісу).

Зміни кліматопів за останні десять років мають місце за даними всіх метеостанцій Українських Карпат. Відповідно до змін клімату, кліматопи стали теплішими, але менш вологими. За даними більшості метеостанцій, за останні десять років кліматоп змінився на один клас як за вологістю, так і теплотою клімату. Однак, за аналізом даних низки метеостанцій зміна гігротопу відбулась на два класи. Переважно це метеостанції на межі регіону (Івано-Франківськ, Львів, Чернівці), або високо в горах (Міжгір'я, Пожижевська, Селятин, Турка), що дає підстави зробити висновок про суттєвіше зменшення кількості опадів саме в цих районах.

Таблиияя 1

\section{Кліматопи за даними метеостанцій Українських Карпат}

\begin{tabular}{|c|c|c|c|c|c|c|}
\hline \multirow[b]{2}{*}{ Метеостанції } & \multicolumn{2}{|c|}{ Клімати трофотопів } & \multicolumn{2}{|c|}{ Клімати гігротопів } & \multicolumn{2}{|c|}{ Кліматоп } \\
\hline & $\begin{array}{c}\text { за багаторічними } \\
\text { даними }\end{array}$ & $\begin{array}{c}2010-2019 \\
\text { роки }\end{array}$ & $\begin{array}{c}\text { за багаторічними } \\
\text { даними }\end{array}$ & $\begin{array}{c}2010-2019 \\
\text { роки }\end{array}$ & $\begin{array}{c}\text { за багаторічними } \\
\text { даними }\end{array}$ & $\begin{array}{c}2010-2019 \\
\text { роки }\end{array}$ \\
\hline Великий Березний & d & e & 5 & 4 & $5 d$ & $4 e$ \\
\hline Долина & $\mathrm{d}$ & e & 7 & 6 & $7 d$ & $6 e$ \\
\hline Дрогобич & e & $\mathrm{e}$ & 5 & 4 & $5 \mathrm{e}$ & $4 \mathrm{e}$ \\
\hline Івано-Франківськ & d & e & 5 & 3 & $5 d$ & $3 e$ \\
\hline Коломия & d & e & 5 & 4 & $5 d$ & $4 \mathrm{e}$ \\
\hline Львів & d & $\mathrm{e}$ & 5 & 3 & $5 d$ & $3 e$ \\
\hline Міжгір’я & d & e & 9 & 7 & $9 d$ & $7 \mathrm{e}$ \\
\hline Пожижевська & $\mathrm{b}$ & $\mathrm{c}$ & 13 & 11 & $13 b$ & $11 \mathrm{c}$ \\
\hline Рахів & d & e & 8 & 7 & $8 \mathrm{~d}$ & $7 \mathrm{e}$ \\
\hline Селятин & $\mathrm{c}$ & d & 8 & 6 & $8 \mathrm{c}$ & $6 \mathrm{~d}$ \\
\hline Славське & $\mathrm{c}$ & d & 8 & 7 & $8 \mathrm{c}$ & $7 d$ \\
\hline Турка & d & e & 8 & 6 & $8 \mathrm{~d}$ & $6 e$ \\
\hline Ужгород & f & f & 4 & 3 & $4 \mathrm{f}$ & $3 g$ \\
\hline Чернівці & e & $\mathrm{f}$ & 4 & 2 & $4 \mathrm{e}$ & $2 f$ \\
\hline Яремча & $\mathrm{d}$ & e & 8 & 7 & $8 d$ & $7 \mathrm{e}$ \\
\hline
\end{tabular}

Встановлені за розрахованими кліматопами тенденції зміни лісорослинних умов в Українських Карпатах за останні роки проходять в двох основних напрямах: а) найбільше підвищення середньомісячних температур повітря спостережено в осінній, зимовий та весняний періоди, а його наслідки мають декілька аспектів: збільшується тривалість вегетаційного періоду, що сприяє підвищенню продуктивності лісів; пришвидшується кругообіг речовин завдяки більшій активності педофауни та більшому обсягу відпаду - покращується трофотоп; триваліший період з плюсовими температурами збільшує об' єм випаровування - зростає сухість гігротопу (погіршуються умови зволоження); зменшення показників від'ємних температур взимку зменшує континентальність клімату; б) зменшення кількості опадів хоча і зафіксовано переважно в зимові місяці, але розширення періоду з середньомісячною температурою вище $0^{\circ} \mathrm{C}$ суттєвіше змінило регіональні гігротопи, ніж трофотопи, тобто по- 
гіршення гідрологічного режиму території наразі $€$ найбільш дієвим чинником впливу глобальної зміни клімату на ліси Карпатського регіону.

Кліматичними показниками, які власне визначають конкурентноздатність лісотвірних порід, $€$ тривалість вегетаційного періоду та сума активних температур. Аналіз літературних даних (Andrianov, 1968; Lipins'kuj, Dyachuk, \& Babichenko, 2003; Barabash, Grebenyuk, \& Tatarchuk, 2007) дав змогу встановити багаторічні значення цих показників для лісорослинних районів Українських Карпат: у рівнинних дубових лісах Придністер'я вегетаційний період триває 165 днів, а сума активних температур $-2500^{\circ} \mathrm{C}$ (метеостанція м. ІваноФранківськ); в дубово-буково-ялицевих лісах Прикарпаття ці значення становлять, відповідно, 140 днів та $1800^{\circ} \mathrm{C}$ (метеостанція м. Долина); в буковоялицево-смерекових гірських лісах - 120 днів та $1200^{\circ} \mathrm{C}$ (метеостанція смт Славське); в смерекових високогірних лісах -90 днів та $700^{\circ} \mathrm{C}$ (метеостан- ція смт Ворохта); в букових гірських лісах Закарпаття - 130 днів та $1500^{\circ} \mathrm{C}$ (метеостанція м. Свалява); в передгірських дубово-букових лісах Закарпаття - 160 днів та $2200^{\circ} \mathrm{C}$ (метеостанція м. Хуст); у рівнинних дубових лісах Закарпаття - 180 днів та $3000^{\circ} \mathrm{C}$ (метеостанція м. Ужгород).

Розрахунки середньої за останні десять років суми активних температур для територій, де розміщені перелічені вище метеостанції регіону, вказують на їх помітні зміни, підвищення яких коливається від $250^{\circ} \mathrm{C}$ у Ворохті, до $600^{\circ} \mathrm{C}$ в Ужгороді (рис. 2). Тренд змін сум активних температур однозначний - відбулось їх зростання у всіх лісорослинних районах, але максимальних значень вони набувають у Закарпатті (метеостанції м. Хуста та м. Ужгорода) - там, де ці суми і так були найвищими. Відносне зростання сум активних температур (у \%) має зворотну тенденцію: максимальне - у гірських умовах (Ворохта, 36\%), мінімальне - у рівнинних (Івано-Франківськ, 16\%).

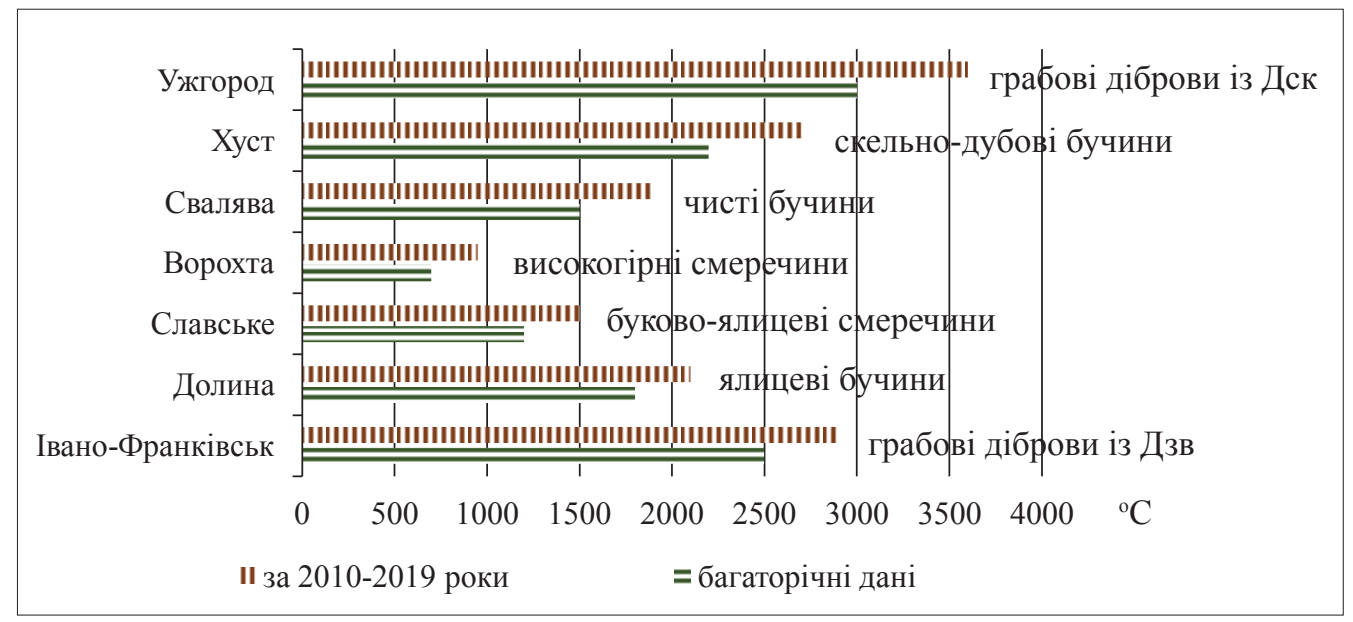

Рис. 2. Зміни суми активних температур на метеостанціях Українських Карпат

Діаграма зміни суми активних температур за метеостанціями регіону (див. рис. 2) наочно ілюструє кліматичну тенденцію останніх років до зміщення висотних поясів рослинності в Українських Карпатах: сума активних температур в поясі високогірних смеречин за останні роки поступово наближається до цього багаторічного показника для поясу буково-ялицевих смеречин; відповідно ця сума для буково-ялицевих смеречин вже досягла суми для чистих бучин і т.д. Тобто, зростання за останні роки суми активних температур дає беззаперечну підставу говорити про тенденцію до поступового підняття (за висотою над рівнем моря) встановлених раніше (Gorshenin \& Shevchenko, 1954; Molotkov, 1966; Golubets, 1978; Gerushyns'kyj, 1996) висотних поясів рослинних формацій (висотних рослинних смуг), а відповідно, і типів лісу.

Представлені вище кліматичні розрахунки підтверджуються змінами в матеріалах лісовпорядкування за різні роки. Наприклад, у гірських лісгоспах чотирьох областей регіону, які розташовані в смузі мішаних буково-ялицево-смерекових типів лісу, з 2000 до 2010 рр. намітились чіткі тенденції щодо зміни площ головних лісотвірних порід зменшується площа смеречин і, відповідно, збільшуються площі яличин, меншою мірою - бучин. Звичайно, ці зміни мають свою специфіку залежно від розташування підприємства. Так, у районі буково-ялицевих лісів (ДП «Берегометське ЛМГ») спостережено збільшення площі бучин за рахунок зменшення площ смеречин та яличин; в районі буково-ялицево-смерекових лісів (ДП «Міжгірське ЛГ») має місце збільшення площ як бучин, так і яличин за рахунок зменшення площі смеречин; у районі ялицево-смерекових лісів (ДП «Ворохтянське ЛГ») і в районі смереково-буково-ялицевих лісів (ДП «Славське ЛГ») також зафіксовано збільшення площі бучин і яличин за рахунок зменшення площі смеречин (рис. 3).

Ці тенденції змін дають підставу зробити висновок, що після повторного (у 2020-му році і пізніше) лісовпорядкування лісового фонду підприємств Карпатського регіону зміни площ головних порід в них будуть ще суттєвішими. 


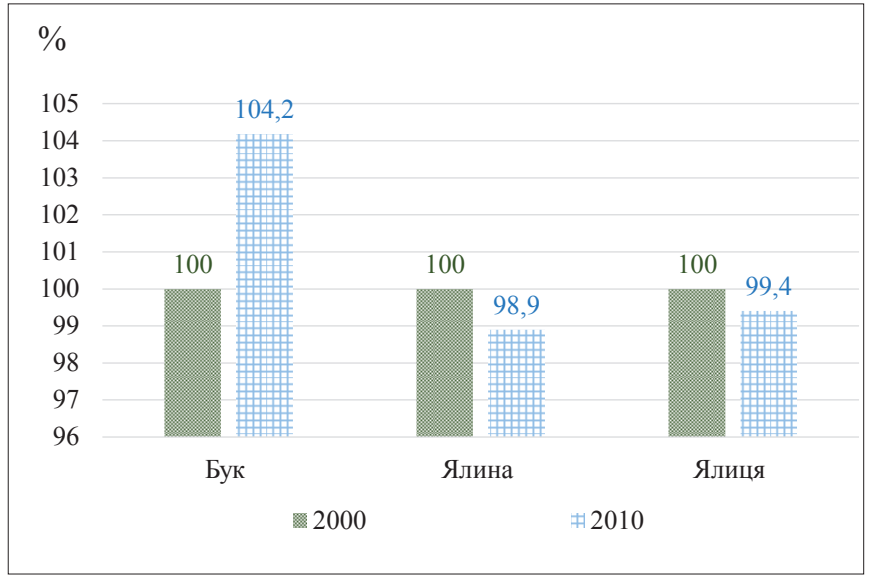

а) ДП «Берегометське ЛМГ»;

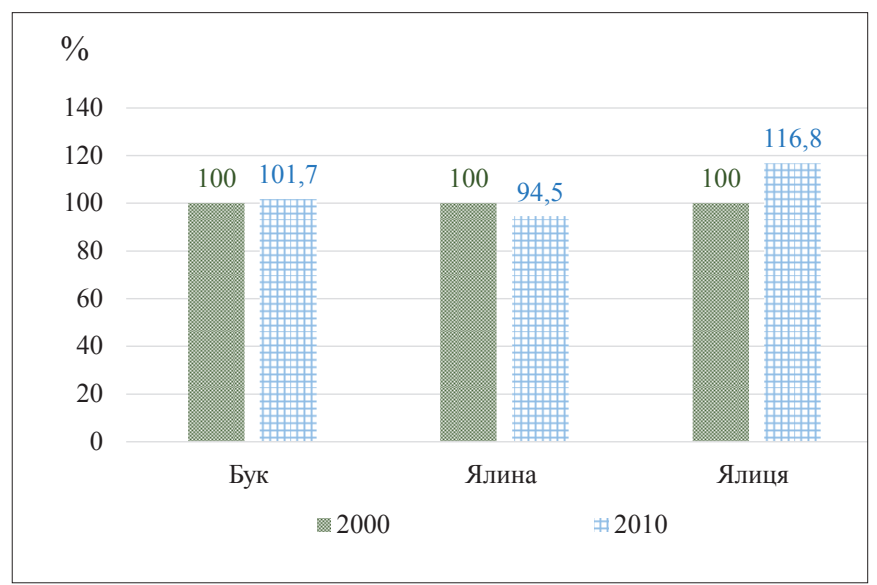

в) ДП «Міжгірське ЛГ»;

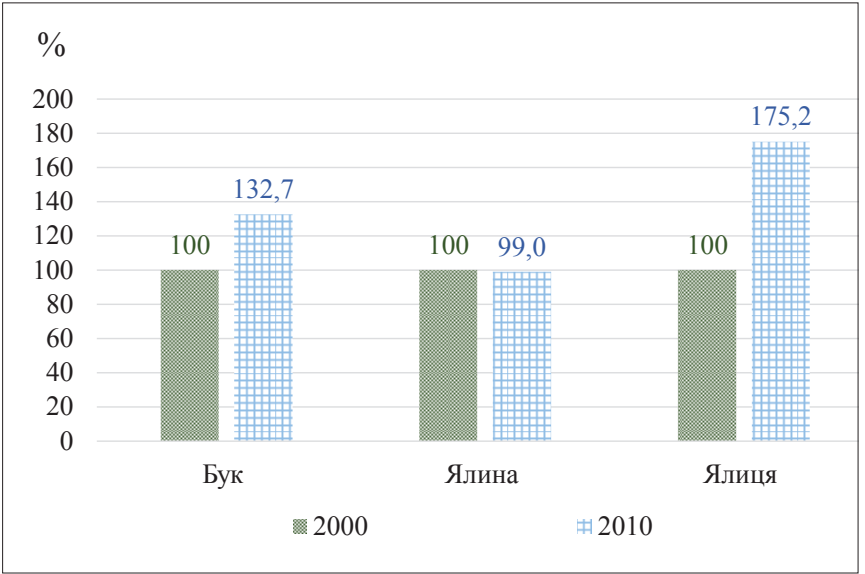

б) ДП «Ворохтянське ЛГ»;

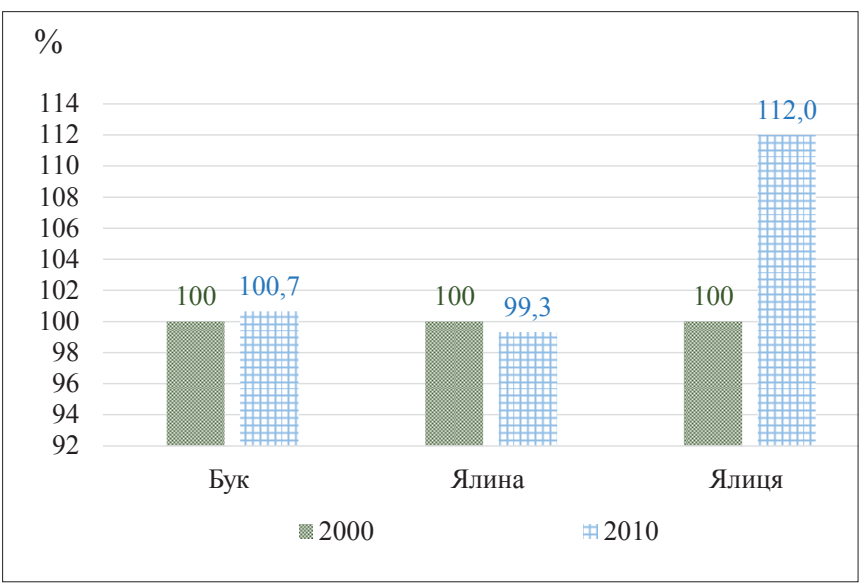

г) ДП «Славське ЛГ»;

Рис. 3. Зміни (у \%) площ основних лісотвірних порід в гірських лісгоспах Українських Карпат

Важливим, а можливо і основним аспектом лісорослинного районування гірських лісів $€$ правильна ідентифікація розташування різних за складом деревостанів за висотою над рівнем моря. Відомо, що більшість лісів Європи (окрім Скандинавії та РФ) розташовані в гірських умовах, оскільки на рівнинних землях переважно вирощують сільськогосподарську продукцію, розташовують населені пункти та промислові підприємства. Однак, в Європейській класифікації типів лісу (76 типів згруповані в 14 категорій) хоча і присутні різні типи гірських лісів, але чітка їхня прив'язка до висоти над рівнем моря відсутня (EEA, 2007). Однак класифікації типів лісу сусідніх з Україною держав у переважній більшості розроблені саме за висотними поясами (Stoyko, 2003; Shparyk \& Viter, 2012; Tretyak \& Chernevyy, 2015).

Так, в Австрії виділяють вісім висотних поясів: до 300 м над рівнем моря - дубові ліси передгір'я Альп і низовин; 300-700 м - грабово-дубові та дубово-букові ліси горбистих височин і долин в горах; 700-900 м - ялицево-смереково-букові ліси низьких гір; 900-1200 м - буково-ялицево-смерекові ліси середньовисоких гір; 1200-1400 м - ялицевосмерекові ліси високих гір; 1400-1800 м - смерекові ліси низького субальпійського поясу; 1800-
2200 м - модринові і соснові ліси субальпійського поясу; вище 2200 м - чагарники альпійського пояcy (Weinfürter, 2013). У Польщі виділено чотири висотні пояси: $\nmid \mathrm{G}$ - долинний гірський з буковими дібровами; Wyż - височинний 3 чистими та мішаними бучинами; $\mathrm{G}$ - нижній гірський 3 мішаними смерічниками; WG - високогірний з чистими смерічниками (Murat, 1998).

У Румунії виділяють п'ять лісових зон, з яких тільки три - гірські: полезахисні лісосмуги з тополі та білої акації степового і лісостепового районів; заплавні ліси з білої тополі, верби білої і ламкої та чорної вільхи; дубові ліси невисоких пагорбів і на схилах передгір'їв (від 200 до 700 м); букові ліси низьких гір (від 400 до 1000 м); хвойні ліси високих гір (від 800 до 1800 м). Як для такої значної кількості лісорослинних зон, загальна кількість типів лісу (69) порівняно невелика (Donita et al., 2008).

Найближчою для Українських Карпат є класифікація висотних поясів Словацької та Чеської республік, яку розробив Alois Zlatnik (1978), зокрема, і на прикладі лісів Закарпаття. Ця класифікація складається 3 дев'яти вегетаційних ступенів (поясів) за висотою над рівнем моря: дубовий - до 300 м; буково-дубовий - від 200 до 400 м; дубово-буковий - від 300 до 500 м; буковий - від 
400 до 800 м; ялицево-буковий - від 500 до 900 м; ялиново-буковий - від 800 до 1200 м; буковоялиновий - від 1000 до 1300 м; ялиновий - від 1100 до 1500 м; гірсько-сосновий - від 1400 до 1800 м (Zlatnik, 1978; Ambros, 1991).

Скориставшись методикою згаданих авторів, Stojko (2009) виділив висотні рослинні смуги (вегетаційні ступені) для південно-західного та північносхідного мегасхилів Карпат. Вони подібні до згаданої вище у класифікації Zlatnik (1978), але їхня кількість збільшена до десяти: дубових лісів з дуба звичайного - на висотах 100-200 м у Закарпатті і 300-350 м у Передкарпатті; ялицево-дубових лісів 3 дуба звичайного - від 350 до 450 м у Передкарпатті; дубових лісів 3 дуба скельного - від 200 до 300 м у Закарпатті; дубово-букових лісів з дуба скельного - від 300 до 400 м у Закарпатті і Буковині; букових лісів - від 400 до 1280 м у Закарпатті і від 450 до 800 м у Передкарпатті; ялицево-букових і буково-ялицевих лісів - від 700 до 1000 м у Закарпатті і від 500 до 900 м у Передкарпатті; смерековоялицево-букових лісів - від 900 до 1100 м у Закарпатті і від 800 до 1000 м у Передкарпатті; смерекових лісів - від 1100 до 1500 м у Закарпатті і від 1000 до 1600 м у Передкарпатті; лісів сосни гірської і душекії зеленої - від 1240 до 1860 м у Закарпатті і від 1400 до 1860 м у Передкарпатті; альпійських лук - від 1860 до 2061 м у Закарпатті і Передкарпатті (Stoyko, 2003). Детальну адаптацію цих поясів для Українських Карпат було здійснено в рамках міжнародного чесько-українського проекту (Holuša, 2010; Shparyk \& Viter, 2012).

Викладені вище результати аналізу щодо зміщення меж лісорослинних зон Українських Карпат під впливом кліматичних змін упродовж останнього десятиріччя та встановлені тенденції зміни складу корінних деревостанів головних порід (Kirschbaum, 2004; Janda et al., 2014; FAO, 2016; Shparyk et al., 2018) дають підставу для внесення змін у висотне поширення рослинних субформацій регіону, а також поправок і доповнень в геоботанічне районування Golubets (2003). Останнє, порівняно 3 іншими видами районувань, $є$ найдетальнішим і враховує особливості породного складу лісостанів не лише окремих поясів (висотних рослинних смуг за Stoyko [2003]), але й районів, що дуже важливо для доволі мозаїчного за типами лісу Карпатського регіону (рис. 4).

Отже, з урахуванням виявлених за результатами досліджень зумовлених кліматом змін у висотному поширенні основних лісотвірних порід, пропонується внести низку доповнень та уточнень у назви існуючих геоботанічних районів Українських Карпат (Golubets, 2003). Окрім того, доцільно визначити базовий тип лісу для цих геоботанічних районів 3 урахуванням динаміки їх кліматопів.

Отже, поправки та уточнення відповідно до результатів досліджень, полягають у такому: 1 - район буково-скельнодубових передгірських лісів Вулканічного хребта з базовим типом лісу «суха нагірна букова судіброва 3 дубом скель- ним», 2 - район буково-скельнодубових лісів Хустсько-Солотвинської улоговини з базовим типом лісу «свіжа нагірна букова судіброва 3 дубом скельним», 3 - район ялицево-букових Верхньодністерських лісів з базовим типом лісу «волога ялицева субучина», 4 - район ялицево-дубових і ялицево-букових передгірських лісів 3 підрайонами: 4a - ялицево-дубові Прикарпатські ліси з базовим типом лісу «свіжа ялицева судіброва», 4б ялицево-букові Покутсько-Буковинські ліси з базовим типом лісу «свіжа ялицева субучина», 5 - район буково-дубових лісів Прут-Сіретського межиріччя 3 базовим типом лісу «свіжа букова судіброва», 6 - район ялицево-букових Верхньоужоцьких лісів 3 базовим типом лісу «волога ялицева субучина», 7 - район грабово-дубово-букових ДубриницькоСвалявських лісів з базовим типом лісу «волога грабово-дубова субучина», 8 - район букових лісів Полонинського хребта 3 базовим типом лісу «волога чиста бучина», 9 - район смереково-ялицевобукових Бескидських лісів з базовим типом лісу «волога смереково-ялицева субучина», 10 - район смереково-ялицево-букових Пригорганських лісів 3 базовим типом лісу «волога смереково-ялицева субучина», 11 - район смереково-ялицево-букових Покутсько-Буковинських лісів 3 базовим типом лісу «свіжа смереково-ялицева субучина», 12 - район смереково-ялицево-букових і ялицево-букових закарпатських лісів з підрайонами: $12 \mathrm{a}$ - ялицевобукові Міжгірські ліси з базовим типом лісу «волога ялицева субучина», 126 - смереково-ялицевобукові Рахівські ліси з базовим типом лісу «волога смереково-ялицева субучина», 13 - район ялинових горганських лісів з підрайонами: $13 \mathrm{a}$ - буковоялицево-смерекові Горганські ліси з базовим типом лісу «волога буково-ялицева сусмеречина», 136 - смерекові Вододільно-Горганські ліси з базовим типом лісу «волога високогірна сусмеречина», 14 - район ялиново-чорногірсько-мармороських лісів 3 підрайонами: $14 \mathrm{a}$ - буково-ялицево-смерекові Верхньотисянські ліси з базовим типом лісу «волога буково-ялицева сусмеречина», 146 - ялицевобуково-смерекові Ворохтянсько-Путильські ліси 3 базовим типом лісу «волога буково-ялицева сусмеречина», 14в - смерекові Чивчино-Мармароські ліси 3 базовим типом лісу «волога високогірна сусмеречина», 15 - район яворово-букових лісів Низькогірних полонин з базовим типом лісу «волога яворова субучина», 16 - район ялівцевих і душекієвих лісів Полонинського хребта 3 базовим типом лісу «сирий ялівцевий (зеленовільховий) субір», 17 - район гірсько-соснових лісів кам'янистих розсипищ Горган з базовим типом лісу «сирий кедрово-гірськососновий субір», 18 - район гірсько-соснових лісів Чорногірського та Чивчинського високогір'я: $18 \mathrm{a}$ - гірсько-соснові ліси Чорногірсько-Гринявського високогір'я 3 базовим типом лісу «сирий душекієво-гірськососновий субір», 186 - гірсько-соснові ліси ЧивчинськоМармароського високогір'я з базовим типом лісу «сирий зеленовільхово-гірськососновий субір». 


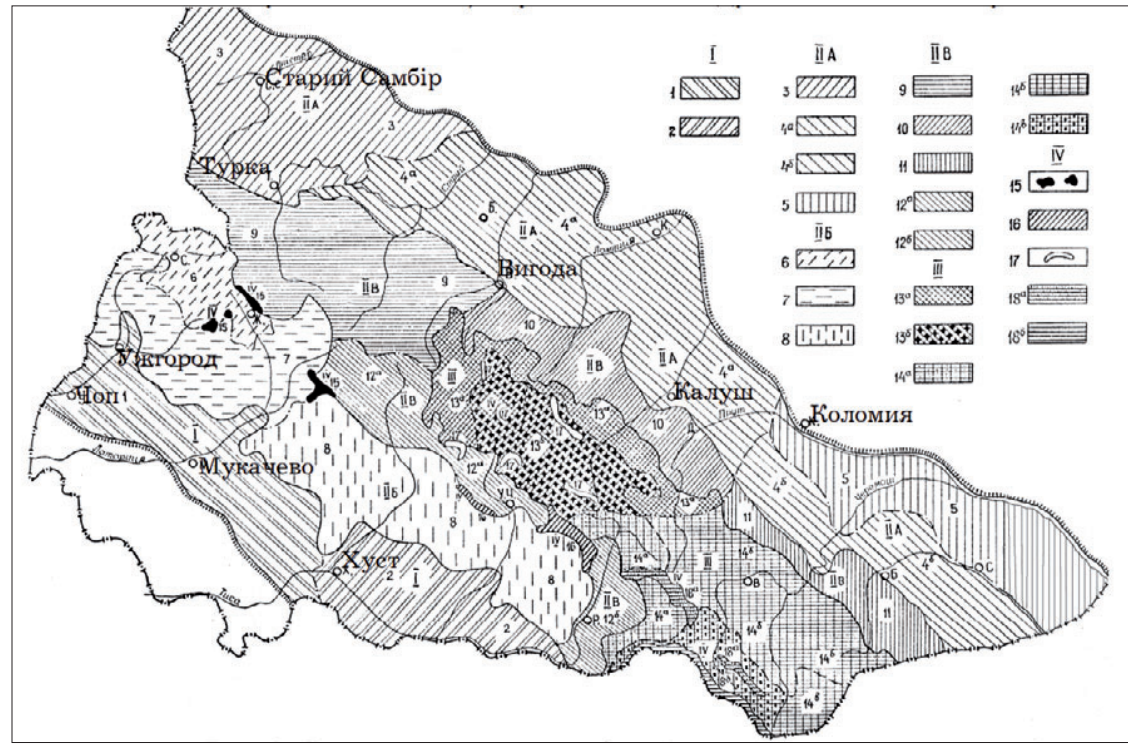

Рис. 4. Схематична карта геоботанічного районування Українських Карпат (1-18 - назви районів) за Golubets (2003): 1 - буково-дубових і дубово-букових передгірських лісів Вулканічного хребта;

2 - дубово-букових і буково-дубових лісів Хустсько-Солотвинської улоговини;

3 - буково-ялицевих верхньодністровських лісів;

4 - ялицево-букових передгірських лісів 3 підрайонами: 4a- Передгірським і 46 - Покутсько-Буковинським;

5 - дубово-букових лісів та остепненої лучної рослинности Прут-Сиретського межиріччя;

6 - ялицево-букових верхньоужоцьких лісів;

7 - грабово-букових і букових дубриницько-свалявських лісів;

8 - букових лісів південного мегасхилу Полонинського хребта;

9 - смереково-ялицево-букових бескидських лісів;

10 - смереково-ялицево-букових і ялицево-смереково-букових пригорганських лісів;

11 - смереково-ялицево-букових і смереково-буково-ялицевих покутсько-буковинських лісів;

12 - смереково-ялицево-букових, смереково-буково-ялицевих і смереково-букових закарпатських лісів

3 підрайонами: $12 \mathrm{a}$ - Міжгірським і 126 - Рахівським;

13 - смерекових горганських лісів 3 підрайонами: 13 а - ялицево-буково-смерекових горганських лісів

і 136 - смерекових вододільно-горганських лісів;

14 - смерекових чорногірсько-мармароських лісів 3 підрайонами: 14а - буково-ялицево-смерекових верхньотиських лісів, 146 - ялицево-буково-смерекових ворохтянсько-путильських лісів, 14в - чистих смерекових чивчинськомармароських лісів;

15 - низькогірних полонин;

16 - щільнодернинних лук, ялівцевих і душекієвих заростей з фрагментами альпійської рослинності середньогірського Полонинського хребта;

17 - мохово-лишайникових пустищ, кам'яних розсипищ і гірськососнин Горган;

18 - сланких гірськососнин у поєднанні з душекієвниками, рододендронниками, субальпійськими та альпійськими луками чорногірсько-мармароського високогір'я з підрайонами: 18а - Чорногірсько-Гринявським

і 186 - Чивчинсько-Мармароським.

Зрозуміло, що ці уточнення назв районів на основі зміни складу деревної рослинності, а разом 3 ними - і типів лісу є певною мірою наближеними і потребують детального подальшого дослідження. Крім того, у зв'язку з кліматичними змінами, відбулися і зміни меж геоботанічних районів. Наведені у статті дані є лише базовою основою для подальших досліджень у цьому важливому напрямі. Результати досліджень дали змогу уточнити породний склад корінних лісів і визначити базові типи лісу в межах існуючого геоботанічного районування Українських Карпат відповідно до змін, спричинених глобальною зміною клімату.

Висновки. Кліматичні зміни останніх десятиріч виявляють суттєвий вплив на лісорослинні умови Українських Карпат, яскравим підтвердженням чого є зміна меж лісорослинних поясів, зміни у складі деревної рослинності, зниження біотичної стійкості окремих деревних видів. Впродовж 20102019 рр. кліматопи Карпатського регіону стали теплішими і сухішими на один, а часто - i на два класи гігротопу. Зміна суми активних температур теж має чіткий тренд до збільшення за даними всіх метеостанцій - від $16 \%$ на рівнині і до $36 \%$ - в гоpax. Відповідно зростає тривалість вегетаційного періоду, що є вагомою причиною змін у складі рослинних субформацій і формацій. Кліматичні зміни привели до змін у площі природного поширення головних порід регіону: окремі з них (ялина) різко зменшила площу свого природного зростання, тоді як інші (бук, ялиця) іiі розширили. 3 продовженням кліматичних змін склад рослинних субформа- 
цій буде і надалі змінюватися природним шляхом. Отже, можна відзначити вже тепер існуючу тенденцію стосовно кліматогенних змін типів лісу в Українських Карпатах.

Найбільші зміни відбуваються в ялинових ліcax. Місце ялини, що всихає, переважно займають ялиця і бук. Поряд 3 цим, у природному поновленні деревостанів за участю ялини, ялиці та бука однозначно переважає бук лісовий і це дає підставу стверджувати, що глобальне потепління в Карпатському регіоні найбільшою мірою покращило лісорослинні умови саме для бука лісового.

Внаслідок кліматичних змін відбулися зміни у породному складі лісів у таких напрямах: а) дубово-букові ліси трансформуються в буководубові зі зміною гігротопу зі «свіжого» на «сухий»; б) буково-ялицеві ліси - в ялицево-букові зі зміною гігротопу з «вологого» на «свіжий»; в) грабовобукові ліси - в грабово-дубово-букові зі зміною гігротопу 3 «вологого» на «свіжий»; г) смерековобуково-ялицеві ліси - в смереково-ялицево-букові або ялицево-букові зі зміною гігротопу з «вологого» на «свіжий»; д) буково-ялицево-смерекові ліси - в смереково-ялицево-букові або ялицево-букові зі зміною гігротопу з «сирого» $\mathrm{i}$ «вологого» на «свіжий»; е) відбулось інтенсивне заростання щільнодернинних лук ялівцевими та душекієвими угрупованнями.

Наступним етапом наукових досліджень повинно стати лісотипологічне картування лісового фонду лісогосподарських підприємств Карпатського регіону під час проведення їх лісовпорядкування відповідно до статті 46 Лісового кодексу України. Варто зазначити, що лісотипологічне впорядкування Карпатського регіону не здійснювалося більше 50 років.

\section{References}

Ambros, Z. (1991). Characteristics of groups of types of geobiocenes of the Czechoslovak Socialist Republic. Brno: Folia Universitatis agriculturae (in Czech).

Andrianov, M.S. (1968). Climate. In Nature of the Ukrainian Carpathians (pp. 87-101). Lviv: Lviv University Publishing House (in Ukrainian).

Barabash, M.B., Grebenyuk N.P., \& Tatarchuk O.H. (2007). Features of changes in heat and moisture resources in Ukraine with modern climate warming. Proceedings Ukrainian Research Hydrometeorological Institute, 256, 174-186 (in Ukrainian).

Cannone, N., Sgrobati, S., \& Guglielmin, M. (2007). Unexpected impacts of climate change on alpine vegetation. Frontiers in Ecology and the Environment, 5 (7), 360-364. https://doi.org/10.1890/15409295(2007)5[360:UIOCCO]2.0.CO;2

Debryniuk, Iu. M. (2011). Dieback of the spruce forests: causes and consequences. Scientific bulletin of the Ukrainian State Forestry University, 21.16,
32-38. Retrieved from http://nltu.edu.ua/nv/Archive/ 2011/21_16/index21_16.htm (in Ukrainian).

Debryniuk, Iu. M. (2003). Forest-cultural zoning of the Western Forest-Steppe of Ukraine. Lviv: Kamula (in Ukrainian).

Didukh, J. P, Chorney, I. I, \& Budzhak, V. V. (2016). Climatogenic changes in the plant world of the Ukrainian Carpathians. Chernivtsi: Druk art (in Ukrainian).

Doniță, N., Bândiu, C., Biriș, I.A., Gancz, V., Apostol, J., \& Marcu, C., (2008). Forest map of Romania by ecosystem units, scale 1: 500 000. Bucureşti: Editura Silvică, (in Romanian).

EEA (2007). European forest types. Categories and types for sustainable forest management reporting and policy, EEA Technical report, 9, $111 \mathrm{pp}$.

European Commission (2019). Roadmap for moving to a low-carbon economy in 2050. Climate action. Retrieved from http://ec.europa.eu/clima/policies/ roadmap/index_en.htm.

FAO (2016). Global forest resources assessment 2015. How are the world's forests changing? Second edition. Rome: FAO. Retrieved from http://www.fao. org/3/a-i4793e.pdf.

Gensiruk, S.A. (1981). Integrated forestry zoning of Ukraine and Moldova. Kyiv: Scientific thought (in Ukrainian).

Gerushinsky, Z.Yu. (1996). Typology of forests of the Ukrainian Carpathians. Lviv: Piramida (in Ukrainian).

Golubets, M.A. (1978). Spruce forests of the Ukrainian Carpathians. Kyiv: Scientific thought (in Russian).

Golubets, M.A. (2003). Geobotanical zoning of the Ukrainian Carpathians is the basis of rational nature management. Proceedings of the Shevchenko Scientific Society, XII: Ecological problems of the Carpathian region, 283-292 (in Ukrainian).

Gorshenin, N.M., \& Shevchenko, S. V. (1954). Forest growing areas of the western regions of the Ukrainian SSR. Scientific notes of the Lvov agricultural institute, 4, 147-156 (in Russian).

Holuša, O. (2010). The system of differentiated management in forest ecosystems of the Ukrainian Carpathians. Fridek-Mistek: UHUL (in Russian).

Ivanenko, B.I. (1977). Forest vegetation zoning of the Kaluga region. Forest magazine, 2, 26-31 (in Russian).

Janda, P., Svoboda, M., Bače, R., Čada, V., Lynn, J., \& Peck, E. (2014). Three hundred years of spatiotemporal development in a primary mountain Norway spruce stand in the Bohemian Forest, central Europe. Forest Ecology and Management, 330 (15), 304-311. https://doi.org/10.1016/j.foreco.2014.06.041

Jump, A. S., Hunt, J.M., \& Peñuelas, J. (2006). Rapid climate change-related growth decline at the southern range edge of Fagus sylvatica. Global Change Biology, 12, 2163-2174.

Kirschbaum, M.U.F. (2004). Direct and indirect climate change effects on photosynthesis and 
transpiration. Plant Biology, 6 (3), 242-253. https:// doi.org/10.1055/s-2004-820883

Kobiv, Yu. Y. (2009). Global climate change as a threat to the species biodiversity of the highlands of the Ukrainian Carpathians. Ukrainian Botanical Journal, 66 (4), 451-465 (in Ukrainian).

Kramarets, V.O., \& Matsyak, I.P. (2018). The role of biotic factors in the spruce forests decline of the Ukrainian Carpathians. Scientific works of the Ukrainian Forestry Academy of Sciences, 17, 121132. https://doi.org/10.15421/411827 (in Ukrainian).

Lavrynenko, D.D. (1978). Fundamentals of forest ecology. Kiev: UACA (in Russian).

Lipins'kuj, V.M., Dyachuk, V.A., \& Babichenko V. M. (2003). Climate of Ukraine. Kyiv: Raevsky Publishing House (in Ukrainian).

Migunova, E.S. (1993). Forests and forest lands. Moscow: Ecology (in Russian).

Molotkov, P.I. (1966). Beech forests and their management. Moscow: Forest industry (in Russian).

Murat, E. (1998). Silviculture. Handbook for forest technicians. Warszawa: Wydawnictwo Swiat (in Polish).

Nazimova, D. I. (1969). The principles of site conditions zoning of mountainous territories (on the example of the Western Sayan). Collection of scientific papers, Types of Siberian forests, Krasnoyarsk, Forest and Timber Institute named after V.M. Sukachev, 101-120 (in Russian).

Posokhov, P.P. (1969). Forest vegetation zoning of the mountain Crimea. Forestry and agroforestry, 16, 105-119 (in Russian).

Shparyk, Yu.S., Berkela Y.Y., Viter R.M., \& Losiuk V.P. (2018). Main types of forest stands dynamics in the Ukrainian Carpathians. Nature of the Carpathians: Annual Scientific Journal of CBR and the Institute of Ecology of the Carpathians NAS of Ukraine, 1 (3), 50-57.

Shparyk, Yu. S., Markiv, P.D., \& Parpan, T. V. (2001). Structure and regeneration of foothill fir forests of the Ukrainian Carpathians. Proceedings of the XI Congress of the Ukrainian Botanical Society, 233234 (in Ukrainian).

Shparyk, Yu.S., Parpan, T.V., Slobodyan, P.Y., Savchyn, T. I., \& Bunij, V.Y. (2013). Spruce forest decline on the north-eastern megaslope of the Ukrainian Carpathians. Scientific bulletin of the Ukrainian National Forestry University, 23.5, 141-147. Retrieved from https://nv.nltu.edu.ua/ Archive/2013/23_5/141_Szp.pdf (in Ukrainian).

Shparyk, Yu. S., \& Viter, R.M. (2012). Identification features of the forest types in Ukrainian Carpathians. Scientific bulletin of the Ukrainian National Forestry University, 22.11, 22-29 (in Ukrainian).

Shparyk, Yu. S., \& Viter, R.V. (2016). Climatope, as the basis of the new forest typological zoning of the Ukrainian Carpathians. Modern problems of forestry and ecological typology, 54-60 (in Ukrainian).

Shukla, P. R., Skea, J., Slade, R., van Diemen, R., Haughey, E., Malley, J., Pathak, M., Portugal Pereira, J. (eds.), (2019). Technical Summary. Climate Change and Land: an IPCC special report on climate change, desertification, land degradation, sustainable land management, food security, and greenhouse gas fluxes in terrestrial ecosystems. Retrieved from https:// www.ipcc.ch/site/assets/uploads/sites/4/2019/11/ 03_Technical-Summary-TS.pdf

Stoyko, S.M. (2003). Geographical peculiarities of vertical differentiation of vegetation cover in the Ukrainian Carpathians. Scientific bulletin of the Ukrainian National Forestry University, 13.3, 4352. Retrieved from https://nv.nltu.edu.ua/Archive/ 2003/13 3/index2.htm (in Ukrainian).

Tretyak, P., \& Chernevyy, Yu. (2015). Features of forest typology in the countries of the Alpine-Carpathian macroregion. Scientific works of the Ukrainian Forestry Academy of Sciences, 13, 237-243. https:// doi.org/10.15421/411534 (in Ukrainian).

Vorob'ev, D. V. (1961). Forest typological classification of climates. Zonal climatypes of forest site types. Proceedings of Kharkov Agriculture Institute, 30, 235-250 (in Russian).

Vorob'ev, D.V. (1967). Methodology of forest typological studies. Kyiv: Harvest (in Russian)

Weinfürter, P. (2013). Silviculture in Austria on an ecological basis. A guide to practice. Wien: PEFC (in German).

Zlatnik, A. (1978). Forest phytocenology. Praha: Státni zemédélski nakladetelstwi (in Czech).

\section{Тенденции динамики типов лесорастительных условий и породного состава древостоев Украинских Карпат в связи с изменениями климата}

\section{Ю.С. Шпарык', Г.Т. Криницкий², Ю.М.Дебрынюк³}

Глобальные изменения климата уже сейчас существенно изменили условия ведения лесного хозяйства в Украинских Карпатах - в резуль-

Шпарык Юрий Степанович - член-корреспондент Лесной академии наук Украины, доктор сельскохозяйственных наук, профессор кафедры лесоводства. Прикарпатский национальный университет имени Васыля Стефаныка, ул. Галицкая, 201, г. Ивано-Франковск, 76008, Украина. Тел.: + 38-0342-596163, +38-050-188-02-61. E-mail: yurii.shparyk@pnu.edu.ua ORCID: https://orcid.org/0000-0001-8047-6356

Криницкий Григорий Томкович - академик Лесной академии наук Украины, Президент ЛАН Украины, доктор биологических наук, профессор, заведующий кафедрой лесоводства. Национальный лесотехнический университет Украины, ул. генерала Чупринки, 103, г. Львов, 79057, Украина. Тел.: 032-237-89-05,+38-067-784-11-60. E-mail: krynytsk@ukr.net

Дебринюк Юрий Михайлович - академик Лесной академии наук Украины, академик-секретарь ЛАН Украины, доктор сельскохозяйственных наук, профессор кафедры лесных культур і лесной селекции. Национальный лесотехнический университет Украины, ул. генерала Чупринки, 103, г. Львов, 79057, Украина. Тел.: 032-235-30-12, +38-067-195-78-36. E-mail: debrynuk ju@ukr.net ORCID: http://orcid.org/0000-0002-0994-349X 
тате массового усыхания ельников многие предприятия вынуждены переориентировать свои лесохозяйственные мероприятия на выращивание товарной древесины других пород. В течение 20102019 гг. климатопы Карпатского региона стали теплее и суше на один, а часто - и на два класса гигротопа. Изменение суммы активных температур в этот период имеет четкий тренд к увеличению по данным всех метеостанций - от $16 \%$ на равнине и до $36 \%$ - в горах. Соответственно растет продолжительность вегетационного периода, что является весомой причиной изменений в составе растительных субформаций и формаций. Климатические изменения привели к изменениям в площади естественного распространения главных пород региона: некоторые из них (ель) резко уменьшили площадь своего естественного ареала, тогда как другие (бук, пихта) - его расширили. С продолжением этих изменений климата состав растительных субформаций будет и в дальнейшем меняться естественным путем. Поэтому, тенденции климатогенных изменений типов леса (лесорастительных условий + состава пород) в Украинских Карпатах необходимо идентифицировать.

Наибольшие изменения происходят в еловых лесах - место ели, которая усыхает, преимущественно занимают пихта и бук. По материалам лесоустройства зафиксировано увеличение площади буковых и пихтовых лесов за счет уменьшения площади ельников в большинстве предприятий лесного хозяйства региона. Наряду с этим, в естественном возобновлении древостоев с участием ели, пихты и бука однозначно преобладает бук лесной и это дает основание утверждать, что глобальное потепление в Карпатском регионе в наибольшей степени улучшило лесорастительных условий именно для бука лесного. Поэтому, актуальным является выявление закономерностей этих изменений для правильного выбора главных пород по типам леса и природным районам. Тенденции динамики лесорастительных условий и породного состава лесов региона идентифицированы по ведомственным данным метеостанций и лесоустройства.

Установлено, что климатогенные изменения лесов Украинских Карпат происходят в таких направлениях: а) дубово-буковые леса трансформируются в буково-дубовые с изменением гигротопа со «свежего» на «сухой»; б) буково-пихтовые леса - в пихтово-буковые с изменением гигротопа с «влажного» на «свежий»; в) грабово-буковые леса - в грабово-дубово-буковые с изменением гигротопа с «влажного» на «свежий»; г) елово-буково-пихтовые леса - в елово-пихтово-буковые или пихтовобуковые с изменением гигротопа с «влажного» на «свежий»; д) буково-елово-пихтовые леса - в еловопихтово-буковые или пихтово-буковые с изменением гигротопа с «сырого» и «влажного» на «свежий»; е) задернелые луга и высокогорные пастбища интенсивно зарастают еловыми, можжевеловыми и зелёно-ольховыми растительными сообществами.
Констатируется насущная необходимость в лесотипологическом картировании лесохозяйственных предприятий Карпатского региона во время проведения их повторного лесоустройства с целью полевой идентификации существующих типов леса.

Ключевые слова: климатогенные изменения лесов; сумма активных температур; количество осадков; лесоустройство; высотные пояса растительности; тип леса; тип древостоя.

\section{Trends of dynamics in the site conditions types and species composition of the forest stands in the Ukrainian Carpathians caused by climate changes}

\author{
Y. Shparyk ${ }^{1}$, H. Krynytskyy², lu. Debryniuk ${ }^{3}$
}

Global climate changes have already significantly changed the conditions for forestry in the Ukrainian Carpathians. Because of the massive spruce forests decline many enterprises are forced to reorient their forestry activities to planting marketable wood of other species. Climatopes of the Carpathian region became warmer and drier by one, and often - by two classes of hygrotopes during 2010-2019. The change in the sum of active temperatures in this period has a clear trend toward an increase according to the data of all regional weather stations - from $16 \%$ in the plain conditions and up to $36 \%$ - in the mountains. Growing season increases accordingly, which is a significant reason for changes in the species composition of subformations and formations. Climatic changes have changed the areas of a natural distribution of the main species in the region: some of them (Norway spruce - Picea abies (L.) H. Karst.) sharply reduced their area, while others (Common beech - Fagus sylvatica L., Silver

Yuriy Shparyk - Corresponding Member of the Forestry Academy of Sciences of Ukraine, Doctor of Agricultural Sciences, Professor, Department of Forestry. Vasyl Stefanyk Precarpathian National University, st. Galytska, 201, Ivano-Frankivsk, 76008, Ukraine. Phone: + 38-0342-596163, + 38-050-188-02-61. E-mail: yurii. shparyk@pnu.edu.ua ORCID: https://orcid.org/0000-0001-80476356

Hryhoriy Krynytskyy - Full Member of the Forestry Academy of Sciences of Ukraine, President FAS of Ukraine, doctor of Biological Sciences, Professor, Head of the Department of Forestry. Ukrainian National Forestry University, 103 General Chuprynka st., Lviv, 79057, Ukraine. Tel.: 032-237-89-05, +38-067-784-1160. E-mail: krynytsk@ukr.net

3 Iurii Debryniuk - Full Member of the Forestry Academy of Sciences of Ukraine, Academician-Secretary of the Ukrainian Forestry Academy of Sciences, Doctor of Agricultural Sciences, Professor of the Department of Forest Crops and Forest Selection. Ukrainian National Forestry University, 103 General Chuprynka st., Lviv, 79057, Ukraine. Tel .: 032-235-30-12, + 38-067-195-7836. E-mail: debrynuk_ju@ukr.net ORCID: https://orcid.org/00000002-0994-349X 
fir - Abies alba Mill.) expanded their areas. With the continuation of actual climate changes, the species composition of plant sub-formations will continue to change by natural way. Therefore, the climatogenic changes in forest types (forest conditions + species composition) in the Ukrainian Carpathians have to be identified.

Right now, the greatest changes are in spruce forests of the Ukrainian Carpathians - the place of Norway spruce, which declined, is mainly occupied by Silver fir and Common beech. According to forest inventory data, an increase in the area of Common beech and Silver fir forests restored due to a decrease in the area of Norway spruce forests practically in all regional forestry enterprises. However, in the natural regeneration of declining forest stands, with the participation of spruce, fir and beech in their species compositions, Common beech clearly prevails, and this suggests that global warming in the Carpathian region has improved site conditions mainly for the beech forests. Therefore, it is relevant to identify the trends of these changes for the correct selection of the main species for the regional forest types and natural altitudinal areas.

It has been found that climatogenic changes in the forests of the Ukrainian Carpathians are going in the following directions: a) oak-beech forests are transforming into beechoak forests with a hygrotope change from «fresh» to «dry».

b) beech-fir forests - into fir-beech forests with a hygrotope change from «wet» to «fresh».

c) hornbeam-beech forests - into hornbeam-oakbeech forests with a hygrotope change from «wet» to «fresh».

d) spruce-beech-fir forests - into spruce-fir-beech or fir-beech forests with a hygrotope change from «wet» to «fresh».

e) beech-spruce-fir forests - into spruce-fir-beech or fir-beech forests with a hygrotope change from «raw» and «wet» to «fresh».

f) soddy meadows and alpine pastures are intensively overgrown with Norway spruce, Common juniper and Green alder plant formations.

The urgent need for forest types mapping for forestry enterprises in the Carpathian region during their next inventory with the aim of field identification of existing forest types is ascertained.

Key words: climatogenic changes in forests; sum of active temperatures; amount of precipitation; forest inventory; altitudinal forest zones; type of forest; type of forest stand. 